\title{
The performance of social responsible investing from retail investors' perspective: international evidence
}

\author{
Guillermo Badía ${ }^{1,2, *}$, Luis Ferruz ${ }^{2}$, and Maria Céu Cortez ${ }^{3}$ \\ ${ }^{1}$ Faculty of Social Science, Nebrija University, Santa Cruz de Marcenado 27, 28015, \\ Madrid, Spain. \\ ${ }^{2}$ Faculty of Business and Economics, University of Zaragoza, Gran vía no. 2, 50005, \\ Zaragoza, Spain. \\ ${ }^{3}$ NIPE - School of Economics and Management, University of Minho, Gualtar, 4710- \\ 057, Braga, Portugal.
}

\begin{abstract}
This paper investigates the performance of socially responsible investment (SRI) portfolios compared to conventional investments. Adopting a retail investor's perspective, we provide evidence of SRI financial performance at the worldwide level as well as at the regional level, for five regions (North America, Europe except UK, UK, Pacific region and Emerging markets). Our results show that the performance of global SRI portfolios is higher than of conventional investments. Also, we observe differences in the financial performance of regional SRI portfolios in the overall period and, in particular, in bear markets. These results suggest that country-specific factors may affect the relationship between corporate social and financial performance.
\end{abstract}

Keywords: Socially responsible investing; Retail investors; Portfolio performance evaluation; Market states; International portfolios.

*Corresponding author: gbadia@ nebrija.es 


\section{Introduction}

Over the last decades, the interest in socially responsible investment (SRI) has grown considerably worldwide. Institutional and retail investors are increasingly willing to incorporate into their investment decisions not only financial criteria, but also the nonfinancial attributes of SRI (Benijts, 2010; Nicolosi et al., 2014). For instance, from 2016 to 2018, sustainable investment assets quadrupled in Japan and increased by $38 \%$ in the United States (GSIA, 2018). And although institutional investors tend to dominate this segment of the market, the interest of retail investors in responsible investing has been steadily growing. In 2012, institutional investors held $89 \%$ of socially responsible assets worldwide compared to $11 \%$ held by retail investors, whereas in 2018 these proportions evolved to $75 \%$ versus $25 \%$, respectively (GSIA, 2018). Despite the significant increase in the number of retail investors committed to a social agenda, previous studies on the financial effects of SRI on portfolio performance have not fully met their concerns. A retail investor is a non-professional investor who buys and sells assets through traditional or online brokerage firms or other types of investment accounts. It is expected that they are less knowledgeable, less disciplined, and less skillful than institutional investors. As such, their investment decisions are usually associated to simple trading strategies (Nilsson, 2016). Also, access to specialized sources of information is more limited and restricted for retail investors than for institutional investors, so retailers usually have little choice but to use open sources of information that are freely available. This issue is even more relevant in the case of sources of social data. Considering the costs associated to obtaining social ratings from well-known data providers, such as KLD or Thomson Reuters ESG, retail investors are left with scarce readily available information on firm's social performance. Therefore, socially responsible investors' security selection process is a challenging task.

It is also worth mentioning that although the asset allocation of retail investors can be broad, they typically invest more in stocks than other types of assets because of their accessible price compared to bonds or currencies (Williams, 2011). Also, investing in more complex financial products such as derivatives poses a great challenge for retail investors, who usually lack the ability to fully understand some complex payoff profiles (Entrop et al., 2016). Because of their small purchasing power, retail investors often pay higher fees on their trades. Nevertheless, the technological developments in trading systems have reduced transaction costs and commissions, thereby encouraging retail 
investors to trade and leading to an increase in the trading volume and liquidity (Butt \& Virk, 2017). Also, retailers now have access to more trading tools than ever before, and investing in international markets has been made quite accessible. Furthermore, it is generally recognized that investor heterogeneity plays a critical role in shaping retail investors' investment decisions. In fact, the literature shows that socioeconomic and demographic characteristics (e.g., gender, age, income, occupation, and education) influence retail investors' social preferences (Wiesel et al., 2016) and also their financial risk tolerance and behavior (Barber \& Odean, 2001). Additionally, retailers differ in terms of social identification (e.g., identity) and performance expectations (Bauer \& Smeets, 2015). In this regard, Derwall et al. (2011) differentiate socially responsible investors between values-driven and profit-seeking investors. To the former, social and personal values are the main drivers to integrate social criteria into investment decisions, so they are even willing to accept losses in financial performance. In turn, to latter, the financial goal is the main purpose of social screening. Although acknowledging this heterogeneity, we evaluate the financial performance of SRI portfolios formed without assuming any particular retail investors' preferences. By doing so, our findings on the SRI portfolio performance depends neither on demographic characteristics of retailers, such as wealth and education, neither on other financial characteristics such as the size of the portfolios.

Finally, despite the increasing integration and globalization of financial markets, previous studies show that country and regional differences among investors, shaped by cultural aspects, influence the way they view corporate social responsibility (CSR) practices. For instance, differences in national cultures have been recognized as affecting the success of CSR practices that firms implement in different markets (Campbell et al., 2012). Also, Brammer et al. (2006) note that stakeholders' expectations in terms of corporate social performance have increased in recent years, although at different rates across countries. The findings of Cortez et al. (2012) confirm geographical differences in the investment style of socially responsible fund managers. And regardless of cultural differences, retail investors are more likely to exhibit home bias (Grinblatt \& Keloharju, 2001), as it is expected that they possess more information on firms close to their home country/region than foreign firms. Therefore, any worldwide evaluation on the financial performance of SRI portfolios from the point of view of retail investors should also assess the financial consequences of investing in a socially responsible at a regional level. 
The main objective of this study is to evaluate the performance of worldwide portfolios that can be formed by socially conscious retail investors. In particular, we aim to assess the financial impact of investing based on social information from free and available sources and the extent to which the performance of such a strategy differs from that of conventional investments. To this end, we form a synthetic portfolio based on the stocks listed on the 'Global-100 Most Sustainable Corporations in the World' list (Global-100, hereafter) and compare its financial performance to the S\&P Global 100 Index. The Global-100 list is freely accessible, so it is a simple and easy-to-use tool for retail investors to identify socially responsible stocks worldwide. This list includes firms from different markets, such as Australia, Japan, and the United Kingdom, so we can account for home preferences of retailers. Additionally, since the period under analysis includes different market states (e.g., the international financial crisis and the Euro sovereign debt crisis), we ascertain whether retail investors' performance may be affected by bull and bear markets.

Considering the growing interest of retail investors in socially responsible issues and the gap in the existing literature addressing worldwide SRI strategies based on accessible social information, the main contribution of this study is to draw light on the financial consequences of investing in firms that retail investors can easily identify as being socially responsible. This analysis is performed both at the worldwide and regional level. Although Brzeszczyński and McIntosh (2014) also use the Global-100 to identify socially responsible opportunities, their analysis is limited to UK stocks included in the list. The extension of SRI research to other geographical areas is further motivated by Auer \& Schuhmacher (2016), who find that the geographical focus of investment affects the relationship between corporate social and financial performance. Using a 6-factor model of performance evaluation (an in Fama \& French, 2018), we find that firms listed in the Global-100 outperform the S\&P Global 100 Index, indicating that a strategy of investing globally with social criteria lead to better results relative to conventional investments. We also find the financial performance of SRI portfolios differs among firms of different regions. While the performance of socially responsible firms from regions such as North America and Europe is neutral, firms from Asia-Pacific show negative performance. The regional differences in performance are also observed in periods of bear markets. We discuss these findings in light of how CSR factors are perceived and recognized in different contexts worldwide. 
The structure of the paper is as follows: Section 2 presents an overview of the related literature. Section 3 describes the data and Section 4 presents the research methods used. Section 5 contains and details the empirical results and Section 6 summarizes our main findings and offers some concluding remarks.

\section{Literature Review}

There are two contrasting hypotheses regarding the performance of portfolios of socially responsible companies. The underperformance hypothesis is supported by modern portfolio theory (Markowitz, 1952), which points out the limitations of using a restricted set of investment opportunities, namely the loss of portfolio diversification. Nevertheless, consistent with stakeholder theory (Freeman, 1984), proponents of SRI claim that socially screened investments may benefit from a higher financial performance as a result of selecting companies that are better able to respond to the concerns of all stakeholders (Jensen, 2001). The issue of whether considering social screens has a positive or negative effect on the financial performance of investment portfolios has been the focus of many empirical studies. These studies, as Osthoff (2015) notes, are primarily focused on the performance of SRI mutual funds (e.g., Bauer et al., 2005; Cortez et al., 2009, 2012; Renneboog et al., 2008; Schröder, 2007; Statman, 2006). The findings of these studies are relevant for institutional investors and for retail investors interested in investing in actively managed SRI mutual funds. However, as Auer and Schumacher (2016) point out, evaluating the impact of incorporating social screens by analyzing the performance of SRI mutual funds has some limitations. One is that there is some evidence that the label 'socially responsible' might be more of a marketing strategy, thus not assuring investors that a SRI fund is truly socially responsible. The issue of whether SRI funds are simply conventional funds in disguise has been recently debated in the literature. For instance, Wimmer (2013) shows that the social level of SRI funds largely disappears after two years. In turn, Utz and Wimmer (2014) find that, on average, SRI funds do not hold more ethical stocks than conventional funds and that the SRI classification does not ensure the exclusion of socially controversial firms. Humphrey et al. (2016) further reinforce the argument that SRI funds and conventional funds are not so different after all and Statman and Glushkov (2016) even find evidence of closet SRI funds, which are conventional funds that avoid investing in unethical stocks. In this context, investors may find it 
difficult to know the extent to which a SRI fund is really considering social criteria in their selection process.

Another stream of the literature evaluates the financial performance of SRI forming portfolios based on corporate social ratings provided by specialized rating agencies. For example, Kempf and Osthoff (2007), Galema et al. (2008), Derwall et al. (2011), and Borgers et al. (2013) evaluate the financial performance of US firms by using the KLD Research \& Analytics database. Other sources of social data for US firms are used by Derwall et al. (2005) and Halbritter and Dorfleitner (2015), namely Innovest and ASSET4, respectively. Regarding European markets, Auer (2016) uses corporate social scores from Sustainalytics, whereas Brammer et al. (2006) use ratings from EIRIS, and Van de Velde et al. (2005) from Vigeo. Moreover, Auer and Schuhmacher (2016), and Gonenc and Scholtens (2017) perform a worldwide analysis of SRI portfolios based on Sustainalytics and ASSET4, respectively. The majority of these studies find that considering CSR aspects in the portfolio selection process does not hurt portfolio financial performance. However, these studies rely on the use of proprietary and costly social databases, which are not typically available to retail investors. As Brzeszczyński \& McIntosh (2014) note, such screening strategies would only be available to institutional investors since this type of data is not at hand for retail investors.

There are some studies that base sustainable investment strategies on free and accessible information on corporate social performance. However, this evidence is, in many cases, focused on a specific dimension of corporate social responsibility, such as reputation or employee satisfaction. Furthermore, this type of evidence is geographically limited, as it addresses the US and UK markets. For instance, Edmans (2011) analyzes portfolios formed on the ' 100 Best Companies to Work For in America' in order to evaluate the financial performance of a strategy of investing in companies with high levels of employee satisfaction. He shows that from 1984 to 2009 firms with stronger employee satisfaction have positive risk-adjusted returns as measured by the 4-factor Carhart (1997) model. The results of Edmans (2011) are consistent with two previous studies (Filbeck \& Preece, 2003; Fulmer et al., 2003) that also find that stocks in this list outperform a matched portfolio of conventional stocks. Also based on the ' 100 Best Companies to Work for in America' list, Carvalho and Areal (2016) investigate the effects of financial crises on the financial performance of SRI portfolios. By applying a dummy variable to the 4-factor Carhart (1997) model, they find that the financial performance of socially 
responsible firms remains unaffected in bear markets. In addition, Anginer and Statman (2010) assess the relationship between corporate reputation and stock returns by evaluating the performance of portfolios composed by Fortune magazine's annual list of 'America's Most Admired Companies'. They find that high-ranked firms underperform low-ranked ones, although they only do so significantly when measuring performance using the CAPM model rather than using Carhart's (1997) 4-factor model. In turn, Filbeck et al. (2009) analyze the long-term return performance of portfolios composed by the ' 100 Best Corporate Citizens' published by Business Ethics magazine over the period 20002007. Through a range of risk-adjusted performance measures, such as the Sharpe (1966) ratio and the 3-factor Fama and French (1993) model, they find that over long holding periods the top 100 socially responsible stocks outperform the S\&P500 stocks, although not performing differently from a matched set of companies. Brammer et al. (2009), based on the same list of socially responsible firms and using the 4-factor model of Carhart (1997), find that these companies perform similar to the market. Filbeck et al. (2013) investigate the financial impact of being listed on different public surveys of exceptional firms from 2000 to 2008 and find that portfolios formed of firms from the Fortune's 'Most Admired Companies' and Business Ethics 'Best Corporate Citizens' lists show statistically significantly positive three and four-factor alphas. Outside the US, Brzeszczyński and McIntosh (2014) investigate the performance of firms from the UK listed on the Global-100 list and find that from 2000 to 2010 the returns of UK socially responsible firms are higher than those of both indices, although the differences are not statistically significant.

In sum, previous studies that explore sustainable investment strategies based on free and accessible information on corporate social performance are mainly focused on the US and UK markets, and many address investment strategies considering specific CSR dimensions. The use of aggregate or individual dimensions of CSR to represent the level of companies' social responsibility is a debatable issue. On the one hand, an analysis of specific dimensions of CSR is likely to be important because different CSR aspects may have differential impacts, depending on the nature of the firm's business (Van De Velde et al., 2005). On the other hand, one can argue that for many investors a firm's overall CSR indicator is more useful than the impact of an individual dimension (BoutinDufresne \& Savaria, 2004). Lee et al. (2013) note that most socially responsible investors do not want to restrict their screens to consider solely environmental, social, or 
governance criteria in their investment decisions. In addition, not all investors have a deep understanding of what, exactly, SRI entails (Wimmer, 2013). Hence, the use of an overall CSR firm score to select sustainable stocks seems pertinent for retail investors. This research thus fills this gap and provides evidence on the financial consequences of investing in a social responsible way by using free and readily available information to form worldwide SRI portfolios.

\section{Data}

In this study, we use the Global-100 list to identify socially responsible stocks. This list was launched in February 2005 and is released annually to report the 100 most sustainable businesses in the world. ${ }^{1}$ Global-100 firms are considered to be socially responsible because they demonstrate, within their industries, a high capacity to integrate environmental, social and governance (ESG) criteria in their activities. We identify stocks included in the Global-100 from January 2005 to December 2014. Monthly discrete returns of all stocks are computed based on the total return series (in US dollars) collected from Thomson Reuters database. To evaluate the long-term performance of SRI portfolios, we use the calendar-time portfolio approach (as in Carvalho \& Areal, 2016). This approach consists in forming an equally-weighted portfolio of the stocks included in the Global-100 list in each year. Portfolios are rebalanced annually at the end of the month in which a new list is announced - each January, before the World Economic Forum in Davos. The list is published on www.global100.org and can be accessed easily and free of charge by any investor interested in engaging in SRI investment strategies. Thus, SRI criteria can easily be included in investment decisions without having to implement a complex social selection process (e.g., screening and engagement).

This paper analyzes the performance of international SRI portfolios of stocks belonging to the list. From 2005 to 2014, firms of 26 countries are represented in the sample. Table 1 shows the country stock allocation of the Global-100 during the full sample period. We can observe that the UK and the US are the most weighted countries in the sample $19.40 \%$ and $16.72 \%$, respectively. In this sense, it appears justified that previous research had focused on these markets. However, the representation of countries such as Japan

\footnotetext{
${ }^{1}$ The Global-100 is managed by Corporate Knights, who also provides indexing solutions and marketbeating portfolios. The composition of the firms in the list can be accessed in https://www.corporateknights.com/reports/global-100
} 
(12.54\%), Canada (6.27\%), and Australia (5.67\%), among others, motivates the analysis of the SRI phenomenon to other geographies. Furthermore, it is worthwhile noting that the highest percentage (32.54\%) of companies is from continental Europe firms. Although other countries are less represented, we note that the list includes firms of emerging markets such as Brazil, India, South Korea or Taiwan, reflecting the fact that firms engaging in SRI practices are not restricted to developed markets.

\section{[Insert Table 1]}

The financial performance of the SRI portfolio is evaluated relative to the S\&P Global 100 Index. This index represents the financial performance of the 100 most important stocks at a global level. ${ }^{2}$ This index was chosen for several reasons. Considering that both the benchmark and the sample of firms should have similar features, Lydenberg and White (2015) point out that benchmarks should be defined by region, size and sector. On that basis, the scope of firms making up the S\&P Global 100 Index is global, just like the scope of the Global-100. Also, the number of firms in the S\&P Global 100 Index is the same as in the Global-100. Their fundamental difference is precisely what we are looking for, i.e., the appeal of following SRI criteria versus capitalization criteria. While the Global-100 firms are rated for specific SRI requirements, the S\&P Global 100 Index firms are selected in terms of their capitalization. ${ }^{3}$

Descriptive statistics on the average monthly returns, standard deviation and risk/reward ratio for the Global-100 portfolio and S\&P Global 100 Index are presented in Table 2. Although the Global-100 portfolio exhibits higher returns than the S\&P Global 100 Index in more years, as well as in the full sample period, these differences are not statistically significant. As to standard deviation, the Global-100 portfolio presents higher levels of risk than the S\&P Global 100 Index in the majority of cases. However, the risk/reward ratio shows that the relation between return and risk (standard deviation in this case) is somewhat better for the Global-100 portfolio than the S\&P Global 100 Index. In panel B, we can see that firms from North America and Europe have higher mean returns and lower standard deviations than firms from Asia-Pacific and Emerging Markets. This is

\footnotetext{
2 These are the firms with the highest capitalization in the S\&P Global 1200. They are considered global businesses, as they earn a large portion of their income doing business in different countries.

${ }^{3}$ As further shown in the robustness checks section, our results are also consistent to the use of alternative benchmarks.
} 
early evidence that there can be differences between the financial performance of firms from different regions.

\section{[Insert Table 2]}

One of the advantages of the forming synthetic portfolios is that the effects of social screening can be assessed without the need to consider transaction costs (Schröder, 2007). ${ }^{4}$ The underlying argument is that, by matching a SRI portfolio to a market index, we are comparing two synthetic portfolios without costs, thereby enabling a fair comparison of both portfolios. By doing so, we are able to isolate the impact of stocks' social characteristics on financial performance. As Schröder (2007) mentions, this approach thus avoids the difficult task of correctly estimating the transaction costs of retail investors. In fact, investors are heterogeneous and fees vary depending on aspects such as the amount of wealth that an investor has available to invest or the broker the investor uses (Brzeszczyński \& McIntosh, 2014). Anyhow, Brzeszczyński and McIntosh (2014) point out that transaction costs would have to be disproportionately high to explain performance differences between SRI and conventional investments. Furthermore, as Brammer et al. (2009) note, when trading occurs only once a year, as in the case of our proposed strategy for retailers, trading costs are likely relatively of a low magnitude. The assumption that socially responsible retailers are not be largely affected by transaction costs is empirically supported by studies such as Kempf and Osthoff (2007) and Auer and Schuhmacher (2016), who find that considering trading fees does not change the main conclusions on the effects of ESG strategies.

\section{Methods}

We evaluate portfolio performance using the 6-factor model (Fama \& French, 2018) that includes the 5-factors of the Fama and French (2015) model augmented by the momentum factor of Carhart (1997). Fama and French (2017) show that the 5-factor model performs well in an international context (North America, Europe, Japan, and Asia Pacific). Although these risk factors have been shown useful in capturing additional sources of

\footnotetext{
${ }^{4}$ Most studies that evaluate the performance of SRI synthetic portfolios do not consider transaction costs (e.g., Borgers et al., 2013; Derwall et al., 2011; Edmans, 2011; Statman \& Glushkov, 2009). The consideration of transaction costs is more relevant in studies that evaluate SRI mutual funds (e.g., Bauer et al., 2005; Chen \& Scholtens, 2018) as they are comparing actively mutual funds (that have an expense ratio) to a market index (which does not consider transaction costs).
} 
systematic risk, none of the previous studies evaluating the financial performance of SRI portfolios considers them. Besides, as in Fama and French (2018), we also account for the momentum factor, which has been shown to be relevant in asset pricing models (Barillas \& Shanken, 2018). The model is estimated as follows:

$$
r_{p t}=a_{p}+b_{p} M k t_{t}+s_{p} S M B_{t}+h_{p} H M L_{t}+r_{p} R M W_{t}+c_{p} C M A_{t}+m_{p} M O M_{t}+e_{p t}
$$

where $r_{p t}$ is the dollar excess return (over the risk-free rate) of portfolio $p$ for month $t$, $M k t_{t}$ is the excess returns of the value-weighted market portfolio for month $t$. The remaining independent variables are the differences between: the returns on diversified portfolios of small and large stocks $\left(S M B_{t}\right)$; high and low book-to-market stocks $\left(H M L_{t}\right)$; stocks with robust and weak profitability $\left(R M W_{t}\right)$; stocks of low and high investment firms - conservative minus aggressive $\left(C M A_{t}\right)$; and winning and losing stocks in the past year $\left(M O M_{t}\right)$. The independent variables are obtained from Professor Kenneth French's website. In this model, $\alpha_{p}$ is the estimated abnormal performance of portfolio $p$, and $b_{p}$, $s_{p}, h_{p}, r_{p}, c_{p}$, and $m_{p}$ represent the estimated coefficients associated with the different risk factors. Finally, $e_{p t}$ represents the zero-mean residuals.

\subsection{Geographical analysis}

As outlined above, besides analyzing performance at the global level, SRI financial performance is analyzed at the regional level. Our international sample includes firms from 26 countries. Considering that a country-specific analysis would result, in some cases, in small sample-size portfolios, we form portfolios at the regional level. Following the MSCI market allocation, we analyze five regions (portfolios): (I) North America, that includes the United States and Canada; (II) Europe (except UK), that includes Austria, Belgium, Denmark, Finland, France, Germany, Ireland, Italy, the Netherlands, Norway, Portugal, Spain, Sweden and Switzerland; (III) United Kingdom; (IV) the Pacific region, that includes Australia, Hong Kong, Japan, New Zealand and Singapore; and (V) Emerging markets, that includes Brazil, India, South Africa, South Korea and Taiwan. This allocation is akin to the one of Fama and French $(1998,2012)$ who group countries in regions mainly by geographic location and market integration. Across the sample period, the average number of stocks in portfolio I (North America) is 22, in portfolio II (Europe ex-UK) 36, in portfolio III (UK) 20, in portfolio IV (Pacific regions) 16, and in portfolio V (Emerging markets) 7. We analyze UK firms and continental Europe firms 
separately not only due to the weight of the UK in the full sample, but also because of the differences of the UK market relative to continental Europe. ${ }^{5}$ Also, separating UK firms from the Europe portfolio allows us to observe the SRI phenomenon on the UK market and to compare our results with previous studies.

\subsection{Identification of different market states}

Since the period under analysis includes different market states (e.g., the international financial crisis and the Euro sovereign debt crisis), we ascertain whether retail investors' performance may differ across bull and bear markets. Recent research analyzes whether the financial performance of SRI is sensitive to different market states (e.g., bull and bear periods). For instance, Lins and et al. (2017) find that throughout the crisis period, US firms with a high levels of CSR perform significantly better than those with a low levels of CSR. Also, Carvalho and Areal (2016) find that the financial performance of socially responsible companies is not affected during periods of market downturn. The sensitivity of portfolio performance to different market phases is even more relevant for retailers since they pay more attention to extreme negative returns than to extreme positive ones (Reyes, 2019). Hence, we explore how SRI portfolios perform in crisis versus non-crisis periods.

We start by identifying the different market states across our sample period using the Pagan and Sossounov (2003), hereafter PS, approach. ${ }^{6}$ PS develop a statistical approach to determine the peaks and troughs of a stock market index. A peak is identified at $t$ time if the event $P K=\left[\ln P_{t-8}, \ldots, \ln P_{t-1}<\ln P_{t}>\ln P_{t+1}, \ldots, \ln P_{t+8}\right]$ occurs, where $P_{t}$ represents the quotation of the relevant stock index, and a trough at time $t$ if the event $T H=\left[\ln P_{t-8}, \ldots, \ln P_{t-1}>\ln P_{t}<\ln P_{t+1}, \ldots, \ln P_{t+8}\right]$ occurs. Consistent with the literature, we identify bear periods as those with a downtrend in the relevant stock market index of at least $20 \%$ from peak to trough. The MSCI ACWI ${ }^{7}$ is used as the relevant stock market index since it is a coherent and complete representation of the market that captures the full spectrum of the global equity opportunity set without home bias. The index includes stocks across 23 developed markets and 23 emerging markets. With 2,480 constituents, the index covers approximately $85 \%$ of the global investable equity

\footnotetext{
${ }^{5}$ The UK financial market is recognized as being more similar to the US than to other continental European markets (Cernat, 2004).

${ }^{6}$ This procedure to identify bull and bear markets is used for instance by Lee et al. (2013), and Carvalho and Areal (2016).

${ }^{7}$ Index prices are in USD. Data is obtained from www.msci.com.
} 
opportunity set. Table 3 shows the global bear market periods (Global-ACWI) identified over the period 2005-2014. The remaining periods are considered bull market periods. However, since this paper examines international socially responsible stock returns, we have to be cautious establishing unique global market states. Considering the different geographic areas of analysis, we thus proceed to identify different market states at the regional level. The relevant stock market indices used are: the MSCI North America Index (portfolio I: North America); the MSCI Europe ex UK Index (portfolio II: Europe except UK); the MSCI United Kingdom Index (portfolio III: United Kingdom); the MSCI Pacific Index (portfolio IV: Pacific); and the MSCI Emerging Markets ex China Index ${ }^{8}$ (portfolio V: Emerging markets). ${ }^{9}$ The regional bear periods are showed in Table 3. The remaining periods are considered as bull periods.

As expected, the downtrend associated to the international financial crisis (from 2007 to 2009) is observed both at the global and regional levels. Furthermore, we observe another bear market period in Europe ex-UK from May 2011 to May 2012, which can be associated to the Euro sovereign debt crisis, as well a bear market period in emerging markets (from May 2011 to September 2011), possibly due to financial contagion of fiscal risks in the US and sovereign debt sustainability in Europe.

\section{[Insert Table 3]}

\subsection{Performance in different market states}

To analyze the market state effect on financial performance we use a conditional 6-factor model with dummy variables, in the spirit of Nofsinger and Varma (2014) and Leite and Cortez (2015). Our model allows risk and performance to vary across different market states by incorporating two dummy variables, as follows:

\footnotetext{
${ }^{8}$ The MSCI Emerging Markets Index includes China as the most representative country. We use the MSCI Emerging Markets ex China Index since China is not included in our sample. Furthermore, the most representative countries in this index are those included in our sample: South Korea 20.62\%, Taiwan $16.79 \%$, India $12.11 \%$, Brazil $10.43 \%$, and South Africa 9.09\%. Anyhow, we computed the analysis with both indices and obtained exactly the same results.

${ }^{9}$ Prices for all indices are in USD. Data is obtained from www.msci.com. Indices used for the remaining regions cover the same countries as our regional portfolios. The MSCI North America Index covers US and Canadian firms; the MSCI Europe ex UK Index covers firms from Austria, Belgium, Denmark, Finland, France, Germany, Ireland, Italy, the Netherlands, Norway, Portugal, Spain, Sweden and Switzerland; the MSCI United Kingdom Index covers stocks from UK; and the MSCI Pacific Index covers firms from Australia, Hong Kong, Japan, New Zealand and Singapore.
} 


$$
\begin{aligned}
& r_{p t}=\alpha_{\text {Bear }} D_{\text {Bear }, t}+\alpha_{\text {Bull }} D_{\text {Bull,t }}+\beta_{1 \text { Bear }} M k t_{t} D_{\text {Bear }, t}+\beta_{1 \text { Bull }} M k t_{t} D_{\text {Bull, } t} \\
& +\beta_{2 B \text { ear }} S M B_{t} D_{\text {Bear }, t}+\beta_{2 B u l l} S M B_{t} D_{\text {Bull }, t}+\beta_{3 \text { Bear }} H M L_{t} D_{\text {Bear }, t} \\
& +\beta_{3 B u l l} H M L_{t} D_{\text {Bull }, t}+\beta_{4 \text { Bear }} R M W_{t} D_{\text {Bear }, t}+\beta_{4 B u l l} R M W_{t} D_{\text {Bull }, t} \\
& +\beta_{5 \text { Bear }} C M A_{t} D_{\text {Bear }, t}+\beta_{5 \text { Bull }} C M A_{t} D_{\text {Bull }, t}+\beta_{6 \text { Bear }} M O M_{t} D_{\text {Bear }, t} \\
& +\beta_{6 B u l l} M M_{t} D_{B u l l, t}+e_{p t}
\end{aligned}
$$

Where $D_{\text {Bear,t }}$ is a dummy variable that takes value of one for bear market periods and zero otherwise and $D_{B u l l, t}$ is a dummy variable that takes value of one for bull market periods and zero otherwise; $\alpha_{\text {Bear }}$ corresponds to the financial performance in bear markets and $\alpha_{\text {Bull }}$ in bull markets; $\beta_{1 \text { Bear }}, \beta_{2 \text { Bear }}, \beta_{3 \text { Bear }}, \beta_{4 \text { Bear }}, \beta_{5 \text { Bear }}$, and $\beta_{6 \text { Bear }}$ correspond to the factor loadings in bear periods; and $\beta_{1 B u l l}, \beta_{2 B u l l}, \beta_{3 B u l l}, \beta_{4 B u l l}, \beta_{5 B u l l}$, and $\beta_{6 B u l l}$ in bull periods.

\section{Results}

\subsection{The performance of SRI portfolios}

Table 4 shows portfolio performance and risk results at the global and regional levels. Panel A displays the results of the Global-100 portfolio (Global) and the S\&P Global 100 Index (S\&P). We also report the results for a difference portfolio, which represents a strategy of going long in the Global portfolio and short in the S\&P portfolio. ${ }^{10}$ While the performance of the Global portfolio is neutral, the S\&P shows a negative and statistically significant performance at the $1 \%$ level. The results show that the difference between the financial performance of the Global portfolio and that of the S\&P is statistically significant at the $0.1 \%$ level, thus indicating that firms listed in the Global-100 outperform those firms listed in the S\&P. These results suggest that retail profit-seeking investors can satisfy their investment demands at a global scope.

\section{[Insert Table 4]}

Panel B of Table 4 reports the results of the regional portfolios. We observe that the financial performance of SRI portfolios of firms from North America, Europe, the UK and Emerging markets is neutral, whereas, firms from the Asia-Pacific region underperform at the $1 \%$ level. This finding suggests that the financial performance of the

\footnotetext{
${ }^{10}$ Although we report estimates on financial performance (alpha) and risk factors (betas), our discussion focuses on the financial performance results, as this is the main focus of this research.
} 
SRI portfolios is geographically dependent. In Table 5 we report the financial performance differences by pairs of regions. The results in this table confirm some differences, namely that socially responsible firms from the Asia-Pacific region underperform those from North America and Europe. In the case of the NA portfolio, the difference is significant at the $1 \%$ level, while for the EU portfolio the statistical significance of the difference is even stronger (at the $0.1 \%$ level). We also find that firms from Emerging markets underperform firms from Europe (at a significance level of 5\%).

\section{[Insert Table 5]}

Our results highlight that different country conditions and cultural aspects seem to affect the valuation of CSR practices. One of the reasons for these differential effects is that stakeholders in different geographical markets attribute different levels of importance to social issues (Kang, 2013). Besides that, our results could be explained by the different maturity levels of the SRI markets considered and their understanding of the effects of integrating CSR issues into corporate strategy. In regions such as North America and Europe, the practice of engaging in in socially responsible initiatives goes further back in time, and investors have progressively been paying more attention to value-relevant CSR information. Yet, in other less developed countries in terms of CSR, market participants may still not perceive the impact of CSR as being positive, consistent with the argument that investment in social and environmental practices may have a negative effect on the short-term financial performance by diverting firm resources from other more practical uses (Kacperczyk, 2009). Our results thus support the relevance of country and regional analysis when assessing the financial performance of SRI portfolios.

Our findings on the potential for socially responsible retail investors to benefit from the outperformance of a SRI strategy relative to conventional investments are novel at the global level and for Pacific and Emerging markets. As for the rest of the markets evaluated, our results are in line with Brammer et al. (2009) and Brzeszczyński and McIntosh (2014), who find a neutral performance of SRI portfolios formed on US stocks listed in the '100 Best Corporate Citizens' and British stocks listed in the '100 'Global100 Most Sustainable Corporations in the World', respectively.

Finally, Table 6 shows the extent to which the financial performance of SRI portfolios may differ in different market conditions. At the global level, we observe that the financial performance of the Global portfolio and the S\&P is similar over different market states. In bear periods, both portfolios show a negative and statistically significant performance 
and the difference between their financial performance is not statistically significant. These results suggest that responsible and conventional firms behave in a similar way when they are experiencing bearish markets. In bull periods, we also find that the financial performance of both portfolios is negative. As such, being responsible at the global level does not imply either a benefit or a cost in different market states compared to conventional investments. Furthermore, the results at the regional level highlight differences between the financial performance of firms in different regions. While in bull periods firms from different regions show similar behavior in terms of financial performance, in bear periods the performance of firms from North America and Europe is neutral, whereas the performance of firms from the UK, Asia-Pacific and Emerging Markets is negative and statistically significant (at the $0.1 \%$ level). The evidence of a worse performance in bear markets is consistent with the argument that in periods of turmoil stockholders consider financial imperatives as prevalent and therefore negatively assess firms' investments on CSR. Turning back to the US, our findings are in line with those of Carvalho and Areal (2016), who find that the financial performance of US socially responsible firms is unaffected during bear market periods. Lins et al. (2017) find that US firms that at the beginning of the crisis period had high CSR ratings perform significantly better than those had a low CSR rating. Our findings differ from those of Lins et al. (2017), but it is important to mention that our results are not comparable to theirs due to differences in the way financial performance is measured. Regarding the UK market, our results are consistent with those of Brzeszczyński and McIntosh (2014) for bull periods.

\subsection{Robustness checks}

Finally, in order to verify the robustness of our results we perform a variety of supplementary checks ${ }^{11}$. On the one hand, alternative financial performance evaluation measures are used. First, we estimate financial performance using the well-established 4factor Carhart (1997) model. We also infer statistical significant differences between the Sharpe (1966) ratio value of the portfolios by means of the Ledoit and Wolf (2008) approach. Finally, we evaluate the financial performance based on lower partial moments using the Sortino ratio (Sortino \& Price, 1994; Sortino \& Van Der Meer, 1991). On the other hand, alternative global indices are used as conventional investment benchmarks.

\footnotetext{
${ }^{11}$ The specific results of this section are not presented for the sake of brevity and because our main results and conclusions are not altered. Nonetheless, detailed results are available upon request.
} 
We compare the financial performance of the Global-100 portfolio to that of the Russell Global Index, the Thomson Reuters Global Index, the S\&P Global 1200 Index, the STOXX Global 1800 Index, the World DataStream Market Index, and the FTSE Global Index. As expected, by using alternative performance measures and benchmarks the results show some variations. However, our main conclusions remain consistent: at the global level, the performance of firms from the Global-100 portfolio is better than that of the S\&P, and at the regional level there are regions that exhibit differentials in SRI portfolio performance.

\section{Conclusions}

The proportion of retail investors basing their strategies on responsible criteria has been increasing considerably. However, most studies on SRI either address the performance of actively managed SRI funds, whose level of social responsibility may be questionable, or are conducted from the perspective of sophisticated or institutional investors who have access to proprietary databases of corporate social information. Research on the performance of SRI portfolios based on free and available information is somewhat scarce, and focuses mainly on the US and the UK markets. This research thus fills this gap and evaluates the financial consequences of investing with social criteria by using readily available information to form worldwide SRI portfolios.

We form a portfolio of firms from the Global-100 list and compare its financial performance to the S\&P Global 100 Index portfolio. Our results show that firms listed in the Global-100 outperform those listed in the S\&P. We also find that the financial performance of socially responsible firms is geographically dependent. An analysis at regional level reveals that firms from North America and Europe show a neutral performance, whereas the performance of firms from Asia-Pacific is negative. Hence, responsible retail investors can benefit from the outperformance of a global sustainable investment strategy relative to conventional investments, although at the regional level financial performance is geographically dependent.

We also evaluate how the financial performance of socially responsible portfolios may be affected by different market conditions. At the global level, we do not observe financial performance differences between firms from the Global-100 and from the S\&P portfolios over different market states. Both portfolios show a negative performance in both bear 
and bull times. However, our results at the regional level shows that firms from different regions show different patterns of performance depending on the state of the market. Firms from North America and Europe perform similarly in different market conditions, whereas the financial performance of firms from the UK, Asia-Pacific, and Emerging markets is negative in bearish periods. Consistent with our previous findings, this evidence suggests that while the performance of socially responsible investors at the global level is not affected by different market conditions, the performance of SRI in specific regions can be negatively affected in times of crisis.

Although the results suggest that in some regions investors have acknowledged the value of CSR activities, we note that CSR is recognized differently in different contexts worldwide. In some regions, especially Asia-Pacific, markets seem to view CSR practices as not being able to generate financial benefits, consistent with a more traditional view that CSR may imply internalizing unnecessary additional costs However, stakeholders from regions such as North America and Europe seem to be able to incorporate valuerelevant CSR information to the extent that any mispricing has disappeared. These results are consistent with different regions being in different levels of maturity levels in terms of how investors assess and incorporate CSR information into the decision-making process. Our findings are thus consistent with the heterogeneity in the patterns of development of SRI across countries (Neher \& Hebb, 2016) and the contextual nature of SRI (Louche \& Lydenberg, 2006).

Overall, our empirical evidence indicates that socially conscious retail investors can invest in SRI worldwide without sacrificing financial performance compared to conventional investments. Also, the different results uncovered at the regional level suggest that country-specific factors may affect the relationship between corporate social and financial performance, as market participants in different regions may have different understandings of the valuation effect of CSR practices. 


\section{References}

Anginer, D., \& Statman, M. (2010). Stocks of admired and spurned companies. Journal of Portfolio Management, 36(3), 71-77. https://doi.org/10.3905/JPM.2010.36.3.071

Auer, B. R. (2016). Do Socially Responsible Investment Policies Add or Destroy European Stock Portfolio Value? Journal of Business Ethics, 135(2), 381-397. https://doi.org/10.1007/s10551-014-2454-7

Auer, B. R., \& Schuhmacher, F. (2016). Do socially (ir)responsible investments pay? New evidence from international ESG data. Quarterly Review of Economics and Finance, 59, 51-62. https://doi.org/10.1016/j.qref.2015.07.002

Barber, B. M., \& Odean, T. (2001). Boys will be Boys: Gender, Overconfidence, and Common Stock Investment. The Quarterly Journal of Economics, 116(1), 261-292. https://doi.org/10.1162/003355301556400

Barillas, F., \& Shanken, J. (2018). Comparing Asset Pricing Models. Journal of Finance, 73(2), 715-754. https://doi.org/10.1111/jofi.12607

Bauer, R., Koedijk, K., \& Otten, R. (2005). International evidence on ethical mutual fund performance and investment style. Journal of Banking and Finance, 29(7), 17511767. https://doi.org/10.1016/j.jbankfin.2004.06.035

Bauer, R., \& Smeets, P. (2015). Social identification and investment decisions. Journal of Economic Behavior and Organization, 117(2005), 121-134. https://doi.org/10.1016/j.jebo.2015.06.006

Benijts, T. (2010). A framework for comparing socially responsible investment markets: An analysis of the Dutch and Belgian retail markets. Business Ethics, 19(1), 50-63. https://doi.org/10.1111/j.1467-8608.2009.01578.x

Borgers, A., Derwall, J., Koedijk, K., \& Ter Horst, J. (2013). Stakeholder relations and stock returns: On errors in investors' expectations and learning. Journal of Empirical Finance, 22, 159-175. https://doi.org/10.1016/j.jempfin.2013.04.003

Boutin-Dufresne, F., \& Savaria, P. (2004). Corporate Social Responsibility and Financial Risk. The Journal of Investing, 13(1), 57-66. https://doi.org/10.3905/joi.2004.391042

Brammer, S., Brooks, C., \& Pavelin, S. (2006). Corporate social performance and stock returns: UK evidence from disaggregate measures. Financial Management, 35(3), 97-116. https://doi.org/10.1111/j.1755-053X.2006.tb00149.x

Brammer, S., Brooks, C., \& Pavelin, S. (2009). The stock performance of America's 100 Best Corporate Citizens. Quarterly Review of Economics and Finance, 49(3), 10651080. https://doi.org/10.1016/j.qref.2009.04.001

Brammer, S., Pavelin, S., \& Porter, L. A. (2006). Corporate social performance and geographical diversification. Journal of Business Research. https://doi.org/10.1016/j.jbusres.2006.04.001

Brzeszczyński, J., \& McIntosh, G. (2014). Performance of Portfolios Composed of British SRI Stocks. Journal of Business Ethics, 120(3), 335-362. https://doi.org/10.1007/s10551-012-1541-x

Butt, H. A., \& Virk, N. S. (2017). Momentum profits and time varying illiquidity effect. Finance Research Letters, 20, 253-259. https://doi.org/10.1016/j.frl.2016.10.010

Campbell, J. T., Eden, L., \& Miller, S. R. (2012). Multinationals and corporate social responsibility in host countries: Does distance matter? Journal of International Business Studies, 43(1), 84-106. https://doi.org/10.1057/jibs.2011.45

Carhart, M. M. (1997). On persistence in mutual fund performance. Journal of Finance, 52(1), 57-82. https://doi.org/10.1111/j.1540-6261.1997.tb03808.x

Carvalho, A., \& Areal, N. (2016). Great Places to Work®: Resilience in Times of Crisis. 
Human Resource Management, 55(3), 479-498. https://doi.org/10.1002/hrm.21676

Cernat, L. (2004). The emerging European corporate governance model: Anglo-Saxon, Continental, or still the century of diversity? In Journal of European Public Policy (Vol. 11, Issue 1, pp. 147-166). https://doi.org/10.1080/1350176042000164343

Chen, X., \& Scholtens, B. (2018). The urge to act: A comparison of active and passive socially responsible investment funds in the United States. Corporate Social Responsibility and Environmental Management, 25(6), 1154-1173. https://doi.org/10.1002/csr.1529

Cortez, M. C., Silva, F., \& Areal, N. (2009). The performance of european socially responsible funds. Journal of Business Ethics, 87(4), 573-588. https://doi.org/10.1007/s10551-008-9959-x

Cortez, M. C., Silva, F., \& Areal, N. (2012). Socially responsible investing in the global market: The performance of US and European funds. International Journal of Finance and Economics, 17(3), 254-271. https://doi.org/10.1002/ijfe.454

Derwall, J., Guenster, N., Bauer, R., \& Koedijk, K. (2005). The eco-efficiency premium puzzle. Financial Analysts Journal, 61(2), 51-63. https://doi.org/10.2469/faj.v61.n2.2716

Derwall, J., Koedijk, K., \& Ter Horst, J. (2011). A tale of values-driven and profit-seeking social investors. Journal of Banking and Finance, 35(8), 2137-2147. https://doi.org/10.1016/j.jbankfin.2011.01.009

Edmans, A. (2011). Does the stock market fully value intangibles? Employee satisfaction and equity prices. Journal of Financial Economics, 101(3), 621-640. https://doi.org/10.1016/j.jfineco.2011.03.021

Entrop, O., McKenzie, M., Wilkens, M., \& Winkler, C. (2016). The performance of individual investors in structured financial products. Review of Quantitative Finance and Accounting, 46(3), 569-604. https://doi.org/10.1007/s11156-014-0479-8

Fama, E. F., \& French, K. R. (1993). Common risk factors in the returns on stocks and bonds. In Journal of Financial Economics (Vol. 33).

Fama, E. F., \& French, K. R. (2015). A five-factor asset pricing model. Journal of Financial Economics, 116(1), 1-22. https://doi.org/10.1016/j.jfineco.2014.10.010

Fama, E. F., \& French, K. R. (2017). International tests of a five-factor asset pricing model. Journal of Financial Economics, 123(3), 441-463. https://doi.org/10.1016/j.jfineco.2016.11.004

Fama, E. F., \& French, K. R. (2018). Choosing factors. Journal of Financial Economics, 128(2), 234-252. https://doi.org/10.1016/j.jfineco.2018.02.012

Filbeck, G., Gorman, R., \& Zhao, X. (2009). The "best corporate citizens": Are they good for their shareholders? Financial Review, 44(2), 239-262. https://doi.org/10.1111/j.1540-6288.2009.00217.x

Filbeck, G., Gorman, R., \& Zhao, X. (2013). Are the best of the best better than the rest? The effect of multiple rankings on company value. Review of Quantitative Finance and Accounting, 41(4), 695-722. https://doi.org/10.1007/s11156-012-0329-5

Filbeck, G., \& Preece, D. (2003). Fortune's best 100 companies to work for in America: Do they work for shareholders? Journal of Business Finance and Accounting, 30(56), 771-797. https://doi.org/10.1111/1468-5957.05362

Freeman, E. R. 1984. (1984). Strategic Management: A Stakeholder Perspective. Piman, Boston.

Fulmer, I. S., Gerhart, B., \& Scott, K. S. (2003). Are the 100 Best better? An empirical investigation of the relationship between being a "great place to work" and firm performance. Personnel Psychology, 56(4), 965-993. https://doi.org/10.1111/j.1744-6570.2003.tb00246.x 
Galema, R., Plantinga, A., \& Scholtens, B. (2008). The stocks at stake: Return and risk in socially responsible investment. Journal of Banking and Finance, 32(12), 26462654. https://doi.org/10.1016/j.jbankfin.2008.06.002

Global Sustainable Investment Alliance - GSIA. (2018). Global Sustainable Investment Review. www.gsi-alliance.org

Gonenc, H., \& Scholtens, B. (2017). Environmental and Financial Performance of Fossil Fuel Firms: A Closer Inspection of their Interaction. Ecological Economics, 132, 307-328. https://doi.org/10.1016/j.ecolecon.2016.10.004

Grinblatt, M., \& Keloharju, M. (2001). How distance, language, and culture influence stockholdings and trades. Journal of Finance, 56(3), 1053-1073. https://doi.org/10.1111/0022-1082.00355

Halbritter, G., \& Dorfleitner, G. (2015). The wages of social responsibility - where are they? A critical review of ESG investing. Review of Financial Economics, 26, 2535. https://doi.org/10.1016/j.rfe.2015.03.004

Humphrey, J. E., Warren, G. J., \& Boon, J. (2016). What is Different about Socially Responsible Funds? A Holdings-Based Analysis. Journal of Business Ethics, 138(2), 263-277. https://doi.org/10.1007/s10551-015-2583-7

Jensen, M. (2001). Value Maximisation, Stakeholder Theory, and the Corporate Objective Function. European Financial Management, 7(3), 297-317. https://doi.org/10.1111/1468-036X.00158

Kacperczyk, A. (2009). With greater power comes greater responsibility? takeover protection and corporate attention to stakeholders. Strategic Management Journal, 30(3), 261-285. https://doi.org/10.1002/smj.733

Kang, J. (2013). The relationship between corporate diversification and corporate social performance. Strategic Management Journal, 34(1), 94-109. https://doi.org/10.1002/smj.2005

Kempf, A., \& Osthoff, P. (2007). The effect of socially responsible investing on portfolio performance. European Financial Management, 13(5), 908-922. https://doi.org/10.1111/j.1468-036X.2007.00402.x

Ledoit, O., \& Wolf, M. (2008). Robust Performance Hypothesis Testing with the Sharpe Ratio. Journal of Empirical Finance, 15(5), 850-859.

Lee, D. D., Faff, R. W., \& Rekker, S. A. c. (2013). Do high and low-ranked sustainability stocks perform differently? International Journal of Accounting \& Information Management, 21(2), 116-132. https://doi.org/10.1108/18347641311312267

Lee, J. S., Yen, P. H., \& Chan, K. C. (2013). Market states and disposition effect: Evidence from Taiwan mutual fund investors. Applied Economics, 45(10), 13311342. https://doi.org/10.1080/00036846.2011.617696

Leite, P., \& Cortez, M. C. (2015). Performance of European socially responsible funds during market crises: Evidence from France. International Review of Financial Analysis, 40, 132-141. https://doi.org/10.1016/j.irfa.2015.05.012

Lins, K. V., Servaes, H., \& Tamayo, A. (2017). Social Capital, Trust, and Firm Performance: The Value of Corporate Social Responsibility during the Financial Crisis. The Journal of Finance, 72(4), 1785-1824. https://doi.org/10.1111/jofi.12505

Louche, C., \& Lydenberg, S. (2006). Socially Responsible Investment: Differences between Europe and United States. Vlerick Leuven Gent Working Paper Series, 22, $1-37$.

Lydenberg, S., \& White, A. (2015). Responsible investment indexes: origins, nature and purpose. In T. Hebb, J. P. Hawley, Andreas G.F. Hoepner, A. L. Neher, \& D. Wood (Eds.), The Routledge Handbook of Responsible Investment (pp. 551-559). 
Routledge. https://doi.org/10.4324/9780203104415-51

Markowitz, H. (1952). The Utility of Wealth. Journal of Political Economy, 60(2), 151158. https://doi.org/10.1086/257177

Neher, A. L., \& Hebb, T. (2016). The responsible investment atlas-an introduction. In T. Hebb, J. P. Hawley, A. G. F. Hoepner, A. L. Neher, \& D. Wood (Eds.), The Routledge Handbook of Responsible Investment (pp. 77-81).

Newey, W., \& West, K. (1987). A Simple Positive Semi-definite, Heteroskedasticity and Autocorrelation consistent Covariance Matrix. Econometrica, 55(3), 703-708.

Nicolosi, M., Grassi, S., \& Stanghellini, E. (2014). Item response models to measure corporate social responsibility. Applied Financial Economics, 24(22), 1449-1464. https://doi.org/10.1080/09603107.2014.925070

Nilsson, J. (2016). Stakeholders of responsible investment: retail investors. In T. Hebb, J. P. Hawley, A. G. F. Hoepner, A. L. Neher, \& D. Wood (Eds.), The Routledge Handbook of Responsible Investment (pp. 485-494).

Nofsinger, J., \& Varma, A. (2014). Socially responsible funds and market crises. Journal of Banking \& Finance, 48, 180-193. https://doi.org/10.1016/j.jbankfin.2013.12.016

Osthoff, P. (2015). What matters to SRI investors? In T. Hebb, J. P. Hawley, A. G. F. Hoepner, A. L. Neher, \& D. Wood (Eds.), The Routledge Handbook of Responsible Investment (Issue 11435, p. 764). Routledge. https://doi.org/10.4324/9780203104415.ch54

Pagan, A. R., \& Sossounov, K. A. (2003). A simple framework for analysing bull and bear markets. Journal of Applied Econometrics, 18(1), 23-46. https://doi.org/10.1002/jae.664

Renneboog, L., Ter Horst, J., \& Zhang, C. (2008). The price of ethics and stakeholder governance: The performance of socially responsible mutual funds. Journal of Corporate Finance, 14(3), 302-322. https://doi.org/10.1016/j.jcorpfin.2008.03.009

Reyes, T. (2019). Negativity Bias in Attention Allocation: Retail Investors' Reaction to Stock Returns. International Review of Finance, 19(1), 155-189. https://doi.org/10.1111/irfi.12180

Schröder, M. (2007). Is there a difference? The performance characteristics of SRI equity indices. Journal of Business Finance and Accounting, 34(1-2), 331-348. https://doi.org/10.1111/j.1468-5957.2006.00647.x

Sharpe, W. F. (1966). Mutual fund performance. The Journal of Business, 39(1), 119138. https://doi.org/10.1007/BF02303300

Sortino, F. A., \& Price, L. N. (1994). Performance Measurement in a Downside Risk Framework. The Journal of Investing, 3(3), 59-64. https://doi.org/10.3905/joi.3.3.59

Sortino, F. A., \& Van Der Meer, R. (1991). Downside risk. Journal of Portfolio Management, 17(4), 27.

Statman, M. (2006). Socially responsible indexes. Journal of Portfolio Management, 32(3). https://doi.org/10.3905/jpm.2006.628411

Statman, M., \& Glushkov, D. (2009). The wages of social responsibility. Financial Analysts Journal, 65(4), 33-46. https://doi.org/10.2469/faj.v65.n4.5

Statman, M., \& Glushkov, D. (2016). Classifying and measuring the performance of socially responsible mutual funds. Journal of Portfolio Management, 42(2), 140151. https://doi.org/10.3905/jpm.2016.42.2.140

Utz, S., \& Wimmer, M. (2014). Are they any good at all? A financial and ethical analysis of socially responsible mutual funds. Journal of Asset Management, 15(1), 72-82. https://doi.org/10.1057/jam.2014.8

Van De Velde, E., Vermeir, W., \& Corten, F. (2005). Corporate social responsibility and financial performance. Corporate Governance, 5(3), 129-138. 
https://doi.org/10.1108/14720700510604760

Wiesel, M., Myrseth, K. O. R., \& Scholtens, B. (2016). Papers in Responsible Banking \& Finance. In Working Papers in Responsible Banking \& Finance (Issue December).

Williams, R. T. (2011). An introduction to trading in the financial markets: trading, markets, instruments, and processes. Elsevier.

Wimmer, M. (2013). ESG-persistence in Socially Responsible Mutual Funds. Journal of Management and Sustainability, 3(1). https://doi.org/10.5539/jms.v3n1p9 


\section{Tables}

Table 1. Country stock allocation

This table presents the country stock allocation of the Global-100 lists during the full sample period. (January 2005 to December 2014). Figures are represented in percentage (\%) of the total number of stocks. The Continental Europe Countries encompass the percentage of European countries excluding UK.

\begin{tabular}{|c|c|c|c|}
\hline Country & $\%$ & Country & $\%$ \\
\hline Australia & 5.67 & Japan & 12.54 \\
\hline Austria & 0.90 & Netherlands & 1.79 \\
\hline Belgium & 1.19 & Norway & 1.79 \\
\hline Brazil & 2.09 & Portugal & 0.60 \\
\hline Canada & 6.27 & Singapore & 1.79 \\
\hline Denmark & 1.79 & South Africa & 0.60 \\
\hline Finland & 2.69 & South Korea & 0.30 \\
\hline France & 5.97 & Spain & 2.39 \\
\hline Germany & 5.07 & Sweden & 4.18 \\
\hline Hong Kong & 0.60 & Switzerland & 2.69 \\
\hline India & 0.90 & Taiwan & 0.60 \\
\hline Ireland & 0.30 & United Kingdom & 19.40 \\
\hline Italy & 1.19 & United States & 16.72 \\
\hline Continental Europe Countries & 32.54 & & \\
\hline
\end{tabular}


Table 2. Descriptive statistics

This table reports descriptive statistics. Panel A shows the mean, standard deviation and reward/risk ratio values of the Global-100 and the S\&P portfolio in the different years and over the overall sample period (from 2005 to 2014). Mean is the monthly arithmetic mean return, SD is the standard deviation, and Reward/Risk ratio is the total return divided by standard deviation. Mean diff (SD diff) is the average return (standard deviation) of the Global-100 portfolio (Global) minus that of the S\&P Global 100 Index (S\&P) with p-values on t-tests (F-test) of equality of means (standard deviations). Panel B displays additional descriptive statistics on the excess returns of the global regional portfolios.

\begin{tabular}{|c|c|c|c|c|c|c|c|c|c|c|}
\hline & \multicolumn{4}{|c|}{ Mean } & \multicolumn{4}{|c|}{ SD } & \multicolumn{2}{|c|}{ Reward/Risk } \\
\hline & Global & $\mathrm{S} \& \mathrm{P}$ & $\begin{array}{c}\text { Mean } \\
\text { diff }\end{array}$ & $t$-test & Global & $\mathrm{S} \& \mathrm{P}$ & SD diff & $F$-test & Global & $\mathrm{S} \& \mathrm{P}$ \\
\hline 2005 & 0.0077 & 0.0024 & 0.0054 & 0.5201 & 0.0279 & 0.0223 & 0.0056 & 1.5614 & 0.2778 & 0.1060 \\
\hline 2006 & 0.0222 & 0.0133 & 0.0089 & 0.9592 & 0.0241 & 0.0213 & 0.0027 & 1.2723 & 0.9230 & 0.6236 \\
\hline 2007 & 0.0052 & 0.0067 & -0.0015 & -0.1287 & 0.0290 & 0.0278 & 0.0012 & 1.0875 & 0.1795 & 0.2416 \\
\hline 2008 & -0.0404 & -0.0407 & 0.0003 & 0.0125 & 0.0697 & 0.0609 & 0.0087 & 1.3064 & -0.5798 & -0.6683 \\
\hline 2009 & 0.0282 & 0.0167 & 0.0115 & 0.3917 & 0.0710 & 0.0727 & -0.0017 & 1.0486 & 0.3973 & 0.2301 \\
\hline 2010 & 0.0119 & 0.0022 & 0.0097 & 0.3583 & 0.0685 & 0.0641 & 0.0043 & 1.1389 & 0.1741 & 0.0343 \\
\hline 2011 & -0.0129 & -0.0054 & -0.0075 & -0.3386 & 0.0557 & 0.0527 & 0.0030 & 1.1162 & -0.2319 & -0.1026 \\
\hline 2012 & 0.0169 & 0.0078 & 0.0091 & 0.4988 & 0.0494 & 0.0399 & 0.0094 & 1.5296 & 0.3422 & 0.1945 \\
\hline 2013 & 0.0125 & 0.0162 & -0.0037 & -0.2796 & 0.0361 & 0.0291 & 0.0069 & 1.5345 & 0.3470 & 0.5582 \\
\hline 2014 & -0.0013 & 0.0001 & -0.0014 & -0.1196 & 0.0296 & 0.0253 & 0.0043 & 1.3734 & -0.0431 & 0.0031 \\
\hline Full period & 0.0050 & 0.0019 & 0.0031 & 0.4890 & 0.0461 & 0.0416 & 0.0045 & 1.2096 & 0.1088 & 0.0463 \\
\hline \multicolumn{11}{|c|}{ Panel B. Global and regional portfolios. } \\
\hline & Global & \multicolumn{2}{|c|}{ S\&P } & $\begin{array}{l}\text { North } \\
\text { merica }\end{array}$ & Europe & \multicolumn{2}{|c|}{$\begin{array}{c}\text { United } \\
\text { Kingdom }\end{array}$} & \multicolumn{2}{|c|}{ Asia-Pacific } & $\begin{array}{l}\text { Emerging } \\
\text { Markets }\end{array}$ \\
\hline Mean & 0.0038 & \multicolumn{2}{|c|}{0.0008} & .0062 & \multicolumn{2}{|l|}{0.0048} & 0.0007 & \multicolumn{2}{|c|}{-0.0015} & -0.0050 \\
\hline Median & 0.0081 & \multicolumn{2}{|c|}{0.0063} & .0065 & \multicolumn{2}{|c|}{0.0053} & 0.0037 & \multicolumn{2}{|c|}{0.0030} & -0.0171 \\
\hline Maximum & 0.1446 & \multicolumn{2}{|c|}{0.0965} & .1003 & \multicolumn{2}{|c|}{0.1988} & 0.1215 & 0.1 & & 0.1604 \\
\hline Minimum & -0.2265 & -0.16 & & 0.1949 & -0.2363 & & 0.2573 & -0.2 & & -0.1441 \\
\hline Std. Dev. & 0.0511 & 0.04 & & .0451 & 0.0651 & & .0540 & 0.0 & & 0.0705 \\
\hline Skewness & -0.7233 & -0.76 & & 0.7513 & $-0.367 \mathrm{C}$ & & 1.0812 & -0.6 & & 0.3781 \\
\hline Kurtosis & 5.8971 & 4.30 & & 5.3743 & 4.2052 & & 5.8351 & $4.2^{\prime}$ & & 2.6434 \\
\hline
\end{tabular}


Table 3. Bear market states

This table identifies periods of bear market according to the Pagan and Sossounov (2003) procedure. The sample period studied is from January 2005 to December 2014. The indices used are the MSCI ACWI Index (Global); the MSCI North America Index (portfolio I: North America); the MSCI Europe ex UK Index (portfolio II: Europe except UK); the MSCI United Kingdom Index (portfolio III: United Kingdom); the MSCI Pacific Index (portfolio IV: Pacific); and the MSCI Emerging Markets ex China Index (portfolio V: Emerging markets). Consistent with literature, we require the rise (fall) of the market being greater (less) than either $20 \%$. We test the window breadth for eight, nine and ten months and obtain the same results.

\begin{tabular}{lcccccc}
\hline \multicolumn{1}{c}{ Portfolio } & Start date & $\begin{array}{c}\text { Index } \\
\text { value } \\
\text { (Points) }\end{array}$ & End date & $\begin{array}{c}\text { Index value } \\
\text { (Points) }\end{array}$ & $\begin{array}{c}\text { Change in } \\
\text { market } \\
\text { index }\end{array}$ & $\begin{array}{c}\text { Length of bear } \\
\text { period (months) }\end{array}$ \\
\hline Global-ACWI & $2007 / 11$ & 408.105 & $2009 / 02$ & 187.168 & -0.5414 & 16 \\
North America & $2007 / 11$ & 1558.805 & $2009 / 02$ & 776.949 & -0.5016 & 16 \\
Europe except UK & $2007 / 11$ & 2452.294 & $2009 / 02$ & 985.823 & -0.5980 & 16 \\
& $2011 / 05$ & 1794.745 & $2012 / 05$ & 1231.996 & -0.3472 & 13 \\
UK & $2007 / 11$ & 1638.644 & $2009 / 02$ & 672.550 & -0.5896 & 16 \\
Pacific & $2007 / 11$ & 2763.476 & $2009 / 02$ & 1369.571 & -0.5044 & 16 \\
Emerging Markets & $2007 / 11$ & 4030.146 & $2009 / 02$ & 1610.415 & -0.6004 & 16 \\
& $2011 / 05$ & 3945.570 & $2011 / 09$ & 3011.914 & -0.2366 & 5 \\
\hline
\end{tabular}


Table 4. Portfolio financial performance and risk estimates

This table shows estimates of performance and risk for portfolios at the global and regional levels over the period January 2005 to December 2014. Panel A reports estimates of the Global-100 portfolio (Global), the S\&P Global 100 Index (S\&P) and the portfolio formed by subtracting the returns of the S\&P Global 100 Index from the returns of the Global-100 portfolio (Diff). Panel B displays estimates of performance and risk for each regional portfolio. P1 corresponds to North America; P2 is Europe ex-UK; P3 is UK; P4 is Pacific; and P5 corresponds to Emerging markets. The estimates for the P5 portfolio start in January 2010, considering there are no stocks from this region previously. Portfolio performance is evaluated by means of the alpha from the 6-factor model (Fama \& French, 2018). The model is estimated by OLS based on the heteroskedasticity and autocorrelation adjusted errors of Newey and West (1987). R2 Adj. is the adjusted coefficient of determination. Values in italics are the $t$-statistics. The asterisks are used to represent the statistically significant coefficients at the $0.1 \%(* * *), 1 \%(* *)$ and $5 \%(*)$ significance levels.

\begin{tabular}{|c|c|c|c|c|c|c|c|c|}
\hline \multicolumn{9}{|c|}{ Panel A. The Global-100 portfolio and the S\&P Global 100 Index. } \\
\hline \multirow{3}{*}{ Global } & Alpha & Mkt & SMB & HML & RMW & CMA & MOM & R2 Adj. \\
\hline & -0.0016 & $1.0232 * * *$ & 0.0865 & 0.0647 & -0.0660 & 0.3805 & $-0.1319 * *$ & 0.9002 \\
\hline & -1.1191 & 23.5065 & 1.1364 & 0.8246 & -0.5199 & 1.9298 & -3.1231 & \\
\hline \multirow[t]{2}{*}{ S\&P } & $-0.0057 * * *$ & $1.0132 * * *$ & $-0.4330 * * *$ & $0.1737 * *$ & 0.1586 & $0.2422 * * *$ & 0.0101 & 0.9770 \\
\hline & -8.8321 & 47.9123 & -10.2345 & 3.2686 & 1.8744 & 3.5231 & 0.5539 & \\
\hline \multirow[t]{2}{*}{ Diff } & $0.0041 * *$ & 0.0100 & $0.5195 * * *$ & -0.1090 & -0.2245 & 0.1382 & $-0.1421 * *$ & 0.2093 \\
\hline & 2.8239 & 0.2339 & 6.1849 & -1.1247 & -1.7122 & 0.7836 & -3.2436 & \\
\hline \multicolumn{9}{|c|}{ Panel B. Regional SRI portfolios. } \\
\hline \multirow{3}{*}{$\mathrm{P} 1$} & Alpha & Mkt & SMB & HML & RMW & CMA & MOM & R2 Adj. \\
\hline & 0.0013 & $0.9252 * * *$ & -0.1535 & 0.0510 & -0.2028 & -0.0185 & -0.0656 & 0.8556 \\
\hline & 0.8000 & 19.5896 & -1.5661 & 0.5933 & -1.9581 & -0.1361 & -1.9485 & \\
\hline \multirow[t]{2}{*}{$\mathrm{P} 2$} & 0.0006 & $1.0599 * * *$ & 0.0355 & -0.0401 & -0.1965 & 0.1392 & -0.0735 & 0.9448 \\
\hline & 0.5079 & 33.5400 & 0.5125 & -0.3196 & -1.3429 & 1.0608 & -1.4094 & \\
\hline \multirow[t]{2}{*}{ P3 } & -0.0041 & $0.8135^{* * *}$ & $0.3616^{* *}$ & -0.0113 & 0.3287 & -0.2579 & -0.0763 & 0.7879 \\
\hline & -1.5918 & 12.7831 & 3.1410 & -0.0520 & 1.3272 & -0.7201 & -0.8158 & \\
\hline \multirow[t]{2}{*}{ P4 } & $-0.0085^{* *}$ & $0.7849 * * *$ & 0.0630 & -0.1333 & 0.0659 & 0.3552 & -0.0360 & 0.7424 \\
\hline & -2.8650 & 10.1728 & 0.8329 & -0.6934 & 0.4660 & 1.8025 & -0.4567 & \\
\hline \multirow[t]{2}{*}{ P5 } & -0.0044 & $1.1116^{* * *}$ & $-0.8084 * *$ & 0.0275 & -0.3214 & 0.2592 & -0.3165 & 0.8680 \\
\hline & -1.1206 & 12.1542 & -3.3568 & 0.0727 & -0.6320 & 0.7960 & -1.7955 & \\
\hline
\end{tabular}


Table 5. Differences in SRI financial performance at the regional level

This table shows the alpha estimates of the difference portfolios between pairs of regions, over the period January 2005 to December 2014. The difference portfolios are formed by subtracting the returns of a regional SRI portfolio from the returns of another one. For instance, for the comparison between portfolios P1 and P2, the returns of the portfolio P2 are subtracted from the returns of the portfolio P1. Alphas are estimated by the 6-factor model (Fama \& French, 2018). The model is regressed by OLS based on the heteroskedasticity and autocorrelation adjusted errors of Newey and West (1987). P1 corresponds to the North America portfolio; P2 to Europe ex-UK; P3 to the UK; P4 to Pacific; and P5 to Emerging markets. Differences regarding the P5 portfolio are estimated from January 2010, considering that previously there are no stocks from this region in the sample. The asterisks are used to represent the statistically significant coefficients at the $0.1 \%(* * *), 1 \%(* *)$ and $5 \%(*)$ significance levels.

\begin{tabular}{lccccc}
\hline & P1 & P2 & P3 & P4 & P5 \\
\hline North America & -- & 0.0006 & 0.0045 & $0.0092^{* *}$ & 0.0017 \\
Europe & & -- & 0.0047 & $0.0094^{* * *}$ & $0.0084^{*}$ \\
United Kingdom & & & -- & 0.0030 & 0.0058 \\
Asia-Pacific & & & -- & 0.0005 \\
Emerging Markets & & & & & -- \\
\hline
\end{tabular}


Table 6. Financial performance in different market states

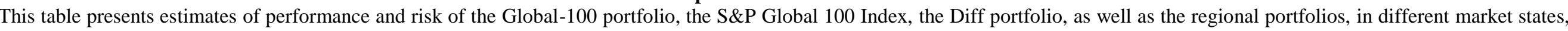

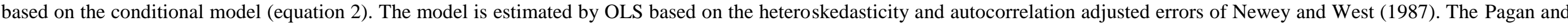

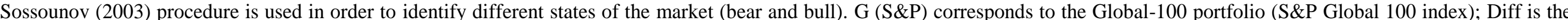

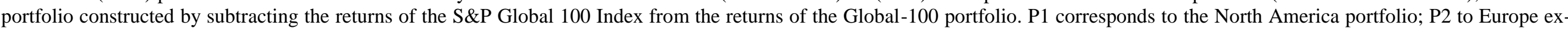

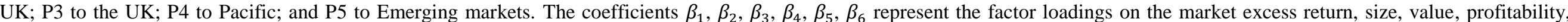

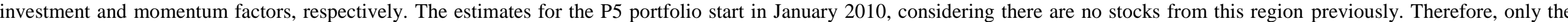

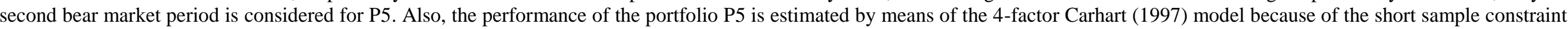

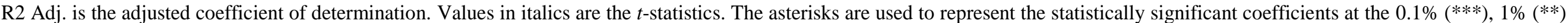
and 5\% (*) significance levels.

\begin{tabular}{|c|c|c|c|c|c|c|c|c|c|c|c|c|c|c|c|}
\hline \multicolumn{16}{|c|}{ Panel A. The Global-100 portfolio and the S\&P Global 100 Index. } \\
\hline \multirow{3}{*}{ Global } & $\alpha_{\text {Bear }}$ & $\alpha_{\text {Bull }}$ & $\beta_{1 \text { Bear }}$ & $\beta_{1 \text { Bull }}$ & $\beta_{2 B e a r}$ & $\beta_{2 B u l l}$ & $\beta_{3 \text { Bear }}$ & $\beta_{3 \text { Bull }}$ & $\beta_{4 B e a r}$ & $\beta_{4 B u l l}$ & $\beta_{5 \text { Bear }}$ & $\beta_{5 \text { Bull }}$ & $\beta_{6 \text { Bear }}$ & $\beta_{6 \text { Bull }}$ & R2 Adj. \\
\hline & $-0.0132 * * *$ & $-0.0028 *$ & $0.7744 * * *$ & $1.0952 * * *$ & $0.7209 *$ & 0.0140 & 0.3848 & 0.1159 & 0.3619 & 0.0008 & 0.4054 & 0.1272 & -0.2615 & -0.0889 & 0.9113 \\
\hline & -3.8610 & -2.0327 & 4.9515 & 39.5901 & 2.3347 & 0.2541 & 1.1836 & 1.3693 & 0.6375 & 0.0077 & 1.3435 & 1.2453 & -1.5432 & -3.7311 & \\
\hline \multirow[t]{2}{*}{$\mathrm{S} \% \mathrm{P}$} & $-0.0097 * * *$ & $-0.0055 * * *$ & $0.9953 * * *$ & $1.0160 * * *$ & $-0.4039 * * *$ & $-0.4223 * * *$ & 0.3535 & 0.1446 & 0.2096 & 0.1602 & 0.3241 & 0.1361 & 0.0580 & 0.0153 & 0.9783 \\
\hline & -5.4656 & -8.4699 & 13.4299 & 48.9675 & -7.5345 & -9.7199 & 1.7290 & 2.7544 & 1.3498 & 1.8281 & 1.7395 & 2.0341 & 0.7515 & 0.7248 & \\
\hline \multirow[t]{2}{*}{ Diff } & -0.0035 & 0.0027 & $-0.2209 *$ & $0.0793^{*}$ & $1.1248 * * *$ & $0.4363 * * *$ & 0.0313 & -0.0287 & 0.1523 & -0.1593 & 0.0813 & -0.0089 & -0.3195 & -0.1041 & 0.2514 \\
\hline & -0.9239 & 1.6546 & -2.3057 & 2.2883 & 3.9034 & 6.0106 & 0.1563 & -0.3053 & 0.3082 & -1.2299 & 0.4127 & -0.0788 & -2.6711 & -3.4275 & \\
\hline \multicolumn{16}{|c|}{ Panel B. Regional SRI portfolios. } \\
\hline \multirow[t]{2}{*}{ P1 } & 0.0015 & -0.0006 & $0.8118 * * *$ & $1.0235 * * *$ & 0.1208 & $-0.2262 *$ & 0.0136 & 0.0549 & -0.5647 & -0.1172 & 0.3956 & -0.2535 & 0.0955 & -0.0486 & 0.8699 \\
\hline & 0.2295 & -0.3420 & 8.2022 & 25.5934 & 0.4649 & -2.4186 & 0.0996 & 0.5072 & -1.4324 & -1.2036 & 2.1681 & -2.8918 & 1.4406 & -1.2862 & \\
\hline \multirow[t]{2}{*}{$\mathrm{P} 2$} & 0.0021 & -0.0007 & $1.0410 * * *$ & $1.0805 * * *$ & -0.0674 & 0.0942 & -0.1991 & 0.0017 & -0.5497 & -0.1460 & 0.2075 & -0.0368 & -0.0941 & -0.0470 & 0.9435 \\
\hline & 0.7539 & -0.4813 & 17.4957 & 22.3968 & -0.5136 & 1.1650 & -1.0720 & 0.0103 & -1.7151 & -0.8275 & 1.2159 & -0.2105 & -1.4613 & -0.8856 & \\
\hline \multirow[t]{2}{*}{ P3 } & $-0.0263 * * *$ & -0.0004 & $0.1881 * *$ & $0.8234 * * *$ & 0.3485 & 0.1620 & -0.2971 & -0.0760 & -0.2118 & 0.2848 & -1.2026 & 0.1473 & -0.9534 & -0.0363 & 0.8735 \\
\hline & -4.4009 & -0.1879 & 3.0980 & 16.8161 & 1.5824 & 1.5176 & -0.6175 & -0.3649 & -0.4197 & 1.0558 & -5.2589 & 0.8640 & -6.4384 & -0.7770 & \\
\hline \multirow[t]{2}{*}{ P4 } & $-0.0192 * * *$ & -0.0064 & $0.8936 * * *$ & $0.7512 * * *$ & $-0.6313^{*}$ & 0.0989 & -0.5203 & -0.0911 & -0.3501 & 0.2048 & 0.4557 & 0.5152 & -0.0520 & -0.1216 & 0.7531 \\
\hline & -3.7382 & -1.7528 & 8.0165 & 8.9025 & -2.0083 & 1.1722 & -1.6926 & -0.3910 & -1.1871 & 1.0903 & 1.4666 & 2.2692 & -0.8856 & -1.2444 & \\
\hline P5 & $-0.0189 * * *$ & -0.0065 & $0.8443 * * *$ & $1.1654 * * *$ & $-2.474 * * *$ & $-0.6497 * *$ & $0.4925 * * *$ & 0.2217 & -- & -- & -- & -- & 0.0289 & -0.2974 & 0.8675 \\
\hline
\end{tabular}

